\title{
PENGARUH REBRANDING APLIKASI MANDIRI ONLINE TERHADAP BRAND EQUITY PADA PENGGUNA APLIKASI MANDIRI ONLINE - NASABAH KCU BANK MANDIRI BANDUNG SURAPATI
}

\author{
Alvi Anjani Alexandra, Evan Jaelani \\ Program Studi Manajemen \\ STIE STAN Indonesia Mandiri, Jl. Jakarta No. 79 Bandung
}

\begin{abstract}
ABSTRAK
Penelitian ini bertujuan untuk menganalisis mengenai pengaruh rebranding terhadap brand equity mandiri online pada Bank Mandiri KCU Bandung Surapati. Teknik penarikan sampel yang digunakan adalah dengan metode non probability sampling dengan teknik incidental. Data diperoleh dari 100 nasabah Bank Mandiri KCU Bandung Surapati. Pengolahan data menggunakan analisis regresi linier sederhana, hasil penelitian ini menunjukkan bahwa rebranding berpengaruh positif signifikan terhadap brand equity. Serta besarnya nilai koefisien determinasi adalah 18,7\%, sisanya $81,3 \%$ dijelaskan oleh variabel-variabel lain yang tidak diteliti yang mempengaruhi brand equity.
\end{abstract}

Kata Kunci : rebranding, brand equity.

\section{PENDAHULUAN}

Indonesia merupakan salah satu Negara yang memiliki potensi besar dalam bidang bisnis e-commerce. Survei yang dilakukan sepanjang 2018 itu menemukan bahwa 171,2 juta orang Indonesia telah terhubung ke internet. Seiring dengan kecepatan dan kemudahan yang ditawarkan oleh internet, kebiasaan berbelanja penduduk Indonesia secara perlahan mulai berkembang dengan memanfaatkan fasilitas internet. Hal ini menjadi alasan beberapa perusahaan perbankan untuk membuat aplikasi mobile banking yang dapat diaskes kapan saja dan masyarakat dapat dengan mudah bertransaksi dengan online tanpa harus datang ke bank melakukan transaksi transfer, setoran, penarikan, pembayaran dan sebagainya.

Hadirnya beberapa aplikasi mobile banking membuat persaingan semakin ketat. Perusahaan perbankan di Indonesia pada akhirnya mulai mengeluarkan aplikasi mobile banking dengan berbagai fitur. Adapun beberapa aplikasi mobile banking di perbankan Indonesia pada tabel 1. 
Tabel 1. Aplikasi Mobile Banking di Perbankan Indonesia

\begin{tabular}{|l|l|l|}
\hline No & \multicolumn{1}{|c|}{ Bank } & \multicolumn{1}{c|}{ Aplikasi } \\
\hline 1. & Bank Central Asia & BCA Mobile \\
\hline 2. & Bank Mandiri & Mandiri Online \\
\hline 3. & Bank Rakyat Indonesia & BRI Mobile \\
\hline 4. & Bank Negara Indonesia & BNI SMS Banking \\
\hline 5. & Bank Standard Chartered & Breeze Indonesia \\
\hline 6. & Citibank & Citi Mobile \\
\hline 7. & CIMB Niaga & Go Mobile \\
\hline 8. & Bank Jabar Banten & Bjb Digi \\
\hline 9. & Bank Mega & Mega Mobile \\
\hline 10. & Bank BII & BII Mobile Banking \\
\hline 11. & Bank Permata & Permata Mobile \\
\hline
\end{tabular}

Sumber: https://id.techinasia.com

Salah satu strategi bersaing yang dapat dilakukan adalah dengan cara membangun merek yang kuat. Merek menurut American Marketing Association (AMA) dalam Kotler (2009:258) adalah nama, istilah, lambang atau desain atau kombinasinya yang dimaksudkan untuk mengidentifikasikan barang atau jasa dari salah satu penjual atau kelompok penjual dan mendiferensiasikan merek dari para pesaing.

Secara tidak langsung sebuah merek akan menggambarkan tujuan dan pangsa pasar yang ingin dikuasai. Seiring dengan pertumbuhan perusahaan, pangsa pasar yang ingin dikuasai juga semakin luas. Jika sebuah merek tidak lagi dapat menggambarkan tujuan dari perusahaan maka yang harus dilakukan adalah melakukan perubahan merek. Banyak penyebab atau alasan perusahaan melakukan perubahan merek pada produknya yang telah dikenal oleh konsumen. Menurut Muller, The Business Of Brand (2004) dalam Ajie Bayu Anggoro (2013) menyatakan alasan dan motivasi perusahaan melakukan perubahan merek adalah untuk merekturisasi, membuat awal yang baru atau penyegaran, pemulihan dari krisis dan skandal, merger, cost control, untuk menyatukan merek secara global, untuk mendukung arah baru, budaya baru perusahaan, dan membentuk produk baru.

Menurut Muzellec et.al (2003) perubahan merek adalah sebuah praktek dari pembentukan nama baru yang merepresentasikan perubahan posisi dalam mind frame para stakeholder dan pembedaan identitas dari kompetitornya.

Proses perubahan merek menunjukkan perubahan yang nyata pada bentuk logo, nama merek, dan slogan. Menurut Stuart dan Muzellec (2004) dalam Mary Lambkin 
and Muzzelec (2006) tiga tipe perubahan tersebut memungkinkan permutasi, sebagai berikut:

1. Perubahan nama dan logo

2. Perubahan nama, logo dan slogan

3. Perubahan logo saja

4. Perubahan slogan dan logo

5. Perubahan slogan saja

Alasan perubahan merek yang dilakukan Mandiri Online adalah untuk menggabungkan antara fitur Internet Banking dengan Mobile Banking dan memudahkan nasabah dalam bertransaksi. Perubahan sebuah merek akan menyebabkan perubahan pada aspek-aspek merek tersebut. Salah satu aspek yang berubah adalah ekuitas merek.

Menurut Kotler (2009:263) menyatakan ekuitas merek adalah nilai tambah yang diberikan pada produk dan jasa. Ekuitas merek dapat tercermin dalam cara konsumen berpikir, merasa, dan bertindak dalam hubungannya dengan merek, dan juga harga, pangsa pasar, serta profitabilitas yang diberikan merek oleh perusahaan.

Sebuah merek mempunyai ekuitas merek yang positif ketika konsumen bereaksi lebih positif terhadap produk dan cara produk itu dipasarkan ketika merek itu teridentifikasi. Bagi konsumen, ekuitas merek dapat memberikan nilai dalam memperkuat pemahaman merek akan proses informasi, memupuk rasa percaya diri dalam pembelian, serta meningkatkan pencapaian kepuasan. Nilai ekuitas merek bagi perusahaan dapat mempertinggi keberhasilan program pemasaran dalam memikat konsumen baru atau merangkul konsumen lama. Hal ini dimungkinkan karena dengan merek yang dikenal maka promosi yang dilakukan akan lebih efektif. Melakukan merek berarti merubah nilai-nilai yang sebelumnya sudah tertanam dalam benak konsumen kemudian menawarkan nilai-nilai yang baru dengan harapan akan memperkuat ekuitas merek atau justru melemahkan. Hal ini berarti perubahan merek yang dilakukan Bank Mandiri KCU Bandung Surapati dapat menimbulkan dampak positif atau dampak negatif bagi perusahaan.

Berdasarkan penelitian terdahulu terdapat beberapa perbedaan hasil penelitian, seperti penelitian yang dilakukan oleh Febriansyah (2013) bahwa pengaruh Rebranding berpengaruh positif terhadap citra merek PT. Telkom. Sedangkan menurut Ariano dan 
Marco (2016) bahwa pengaruh Rebranding berpengaruh negarif terhadap Brand Equity pada Smartphone Microsoft Lumia.

\section{LITERATUR DAN HIPOTESIS}

Definisi brand Menurut Kotler dan Keller (2012 : 263) adalah brand sebagai nama, istilah, tanda, simbol, atau desain, atau kombinasi semuanya, yang dimaksudkan untuk mengidentifikasikan barang atau jasa seseorang atau kelompok penjual dan untuk membedakannya dari barang atau jasa pesaing. Menurut Kotler dan Armstrong (2012 : 255) brand adalah nama, istilah, tanda, simbol, desain, atau kombinasi yang mengidentifikasikan produk atau jasa dari suatu penjual atau kelompok penjual dan membedakan brand dari pesaing brand.

American Marketing Association (AMA), Muzellec et al dalam jurnal Understanding Corporate Rebranding: An Evolution Theory Perspective menawarkan definisi re-branding sebagai sebuah sebuah nama, istilah, simbol atau gambaran tertentu, atau kombinasi ketiganya yang dibentuk membangun merek dengan tujuan membedakan posisi perusahaan yang baru di benak pemangku kepentingan, pesaing dan masyarakat. (Tevi \& Otubanjo, 2013:89). Re-branding dilakukan dengan metode atau cara yang berbeda-beda bagi setiap perusahaan namun memiliki satu tujuan yang sama yaitu mengubah atau meningkatkan citra perusahaan, serta melebarkan pangsa pasar yang berorientasi profit. Menurut (Goi dan Goi, 2011) dalam jurnal (Tevi\&Otubanjo, 2013:92). Adapun proses rebranding yang dilakukan dengan rebranding mix yaitu dengan repositioning, renaming, redesign, dan relaunch penjelasan pada halaman berikutnya.

1. Repositioning ialah proses penyesuaian persepsi sehingga terlihat berbeda dibenak konsumen. Suatu tindakan yang mencoba untuk merubah persepsi konsumen dari suatu merek yang bertujuan untuk menarik perhatian segmen market yang baru. Posisi sebuah merek dalam perbandingan dengan kompetitior.

2. Renaming ialah proses penting dalam rebranding dalam bentuk merubah brand nama yang merupakan dasar untuk awarenes dan communication. Nama baru menjadi media pengirim sinyal yang kuat kepada seluruh stakeholder bahkan perusahaan melakukan perubahan strategi, perubahan fokus dan struktur 
kepemilikan. nama merupakan indikator merek (Muzellec et al : 2003) dalam jurnal (Rusmadani, $2015: 2$ ).

3. Redesign ialah perubahan tampilan visual yang dilakukan seperti logo, office style dan elemen visible lainnya yang ingin disampaikan. Proses rebranding menunjukkan perubahan yang nyata pada bentuk logo, nama merek, dan slogan. Perubahan pada estetika merek dan elemen yang berwujud. Pada redesign ini perusahaan melakukan perubahan pada tampilan. Komponen dalam redesign ini adalah tampilan pada logo, office dan pesan/slogan. inti yang merupakan dari filosofi perusahaan atau atribut utama dari produk yang digambarkan ke dalam sebuah simbol (Gambles dan Schuster, 2003) dalam jurnal (Rusmadani $2015: 3$ ).

4. Relaunch adalah peluncuran atau pemberitahuan brand baru ke dalam internal dan eksternal perusahaan. Untuk internal dapat dilakukan dengan brosur atau buletin, internal meeting, dan juga melalui workshop atau intranet. Sedangkan untuk eksternal dapat melalui press relase, advertising dan media lainnya. untuk menarik perhatian akan brand baru tersebut dan juga dapat memfasilitasi proses adopsi dari nama baru tersebut kepada para stakeholder (Muzellec et al, 2003) dalam jurnal (Rusmadani $2015: 3$ ).

Ekuitas merek adalah seperangkat asosiasi dan perilaku yang dimiliki oleh pelanggan merek, anggota saluran distribusi, dan perusahaan yang memungkinkan suatu merek mendapatkan kekuatan, daya tahan, dan keunggulan yang membedakan dengan para pesaing (David A Aaker, 2013:204). Empat elemen inti ekuitas merek (brand awareness, perceived quality, brand associations, brand loyalty) yang kuat dapat meningkatkan kekuatan elemen ekuitas merek lainnya seperti kepercayaan konsumen, dan lain-lain. (Durianto, dkk, 2004). Menurut Aaker (Tjiptono, 2011:97) dalam Mutmainah, brand equity dapat di formulasikan dari sudut pandang manajerial dan strategi korporat, meskipun landasan utamanya adalah perilaku konsumen.

1. Brand Awareness (Kesadaran Merek) Menurut Aaker (Tjiptono, 2011:97) brand awareness adalah kemampuan konsumen untuk mengenali atau mengingat bahwa sebuah merek merupakan anggota dari kategori produk tertentu. Menurut Keller (2008:54) brand awareness terdiri dari performasi brand recognition dan brand recall. Brand recognition adalah kemampuan konsumen memaparkan suatu merek ketika mengingat merek tersebut sebagai petunjuk. Sedangkan brand recall adalah 
kemampuan konsumen dalam mengingat merek ketika diberikan informasi suatu kategori produk sebagai petunjuk. Berdasarkan definisi di atas dapat disimpulkan bahwa kesadaran merek merupakan kemampuan konsumen untuk mengenali atau mengingat kembali suatu merek dari suatu kategori produk tertentu.

2. Brand Association (Asosiasi Merek) Menurut Aaker (Tjiptono, 2011:98) brand association adalah segala hal yang berkaitan dengan ingatan mengenai sebuah merek. Brand association berkaitan erat dengan brand image, yang didefinisikan sebagai serangkaian asosiasi merek dengan makna tertentu. Asosiasi merek memiliki tingkat kekuatan tertentu dan akan semakin kuat seiring dengan bertambahnya pengalaman konsumen atau eksposur dengan merek spesifik. Menurut Kotler dan Keller (2012:G1) sebagai berikut: "Brand association is all brand-related thoughts, feelings, perceptions, images, experiences, beliefs, attitudes, and so on that become linked to the brand node". Berdasarkan defini diatas dapat disimpulkan bahwa brand association adalah segala hal yang berkaitan persepsi, kepercayaan, dan ingatan mengenai suatu merek.

3. Perceived Quality (Persepsi Kualitas) Menurut Aaker (Tjiptono, 2011:97) perceived quality merupakan penilaian konsumen terhadap keunggulan atau superioritas produk secara keseluruhan. Oleh sebab itu, perceived quality didasarkan paa evaluasi subyektif konsumen (bukan manajer atau pakar) terhadap kualitas produk. Menurut Keller (2008:195) mengemukakan bahwa persepsi kualitas adalah persepsi konsumen terhadap keseluruhan kualitas suatu produk atau layanan yang dibandingkan dengan produk lainnya. Schiffman \& Kanuk (2010:195) menyatakan perceived quality sebagai berikut: "Consumers often judge the quality of a product or service on the basis of a variety of informational cues that they associated with the product, some of these cues are intrinsic to the product or service; other are extrinsic, such as price, store, image, service environment, brand image, and promotional messages". Berdasarkan beberapa definisi dari para ahli dapat disimpulkan bahwa persepsi kualitas adalah persepsi dan evaluasi penilaian konsumen terhadap suatu kualitas atau layanan.

4. Brand Loyalty (Loyalitas Merek) Menurut Aaker (Tjiptono, 2011:98) brand loyalty merupakan suatu ukuran keterkaitan seorang pelanggan kepada sebuah merek. Menurut Schiffman \&Kanuk (2010:88) brand loyalty adalah: "consumers consistent 
preference and/or purchase of the same brand in a specific product or servie category". Sedangkan menurut Peter \& Olson (2005:546) "brand loyalty is an intrinsic commitment to repeatedly purchase a particular brand". Berdasarkan definisi diatas, dapat disimpulkan brand loyalty terjadi apabila konsumen melakukan pembelian terhadap suatu merek tertentu secara berulang.

Penelitian-penelitian terdahulu menyatakan bahwa rebranding ini memiliki pengaruh yang signifikan terhadap brand equity. Seperti penelitian yang dilakukan oleh Febriansyah (2013) menyatakan bahwa hasil penelitiannya adalah rebranding berpengaruh signifikan terhadap brand equity. Berikutnya, penelitian yang dilakukan Mariastuti (2015) juga menyatakan bahwa rebranding berpengaruh signifikan terhadap brand equity. Sedangkan menurut Roslina (2013) menyatakan bahwa rebranding tidak berpengaruh signifikan terhadap brand equity.

H1 : Rebranding berpengaruh positif terhadap Brand Equity.

\section{METODE PENELITIAN}

Populasi dalam penelitian ini adalah seluruh nasabah Bank Mandiri KCU Bandung Surapati yang menggunakan aplikasi mandiri online, Teknik sampling yang digunakan dalam penelitian ini adalah nonprobability sampling adalah teknik pengambilan sampel yang tidak memberi peluang/kesempatan sama bagi setiap unsur atau anggota populasi untuk dipilih menjadi sampel. Serta menggunakan incidental sampling, hal ini karena tidak semua nasabah menggunakan aplikasi mandiri online, sehingga untuk memudahkan ketika ada nasabah datang ke Bank Mandiri KCU Bandung Surapati langsung ditanya apakah mereka menggunakan mandiri online lebih dari 1 (satu) tahun, ketika jawabannya iya, maka langsung dijadikan sebagai sampel. Dengan menggunakan rumus Bernoulli, Adapun tingkat ketelitian $(\alpha)$ yang ditentukan $10 \%$, tingkat kepercayaan $90 \%$ sehingga diperoleh nilai $\mathrm{Z}=1.96$, tingkat kesalahan ditentukan sebesar 10\%. Sementara itu probalitas kuesioner benar (diterima) yaitu 0.5 dan ditolak (salah) yaitu $(1-0.5=0.5)$ berikut ini adalah perhitungannya, $\mathrm{n} \geq(1.96)^{2}$. $0.5 .0 .5 /(0.01)^{2}=96,4$. Sehingga sampel yang digunakan minimal adalah sebanyak 97 orang, dengan sampel yang digunakan dalam penelitian ini adalah sebanyak 100 orang. Penelitian dilakukan selama periode bulan juni sampai dengan September 2019. 


\section{TEMUAN-TEMUAN}

\subsection{Statistik Deskriptif}

Berikut adalah resume tanggapan responden terhadap variabel Rebranding:

Tabel 2. Resume Rebranding

\begin{tabular}{|c|c|c|c|c|}
\hline No. & Indikator & Pernyataan & Skor & Kriteria \\
\hline \multirow{3}{*}{1} & \multirow{3}{*}{ Repositioning } & $\begin{array}{l}\text { Desain dalam aplikasi Mandiri Online } \\
\text { terlihat menarik }\end{array}$ & 438 & $\begin{array}{l}\text { Sangat } \\
\text { Tinggi }\end{array}$ \\
\hline & & $\begin{array}{l}\begin{array}{l}\text { Aplikasi Mandiri Online mudah untuk } \\
\text { digunakan }\end{array} \\
\end{array}$ & 431 & $\begin{array}{l}\text { Sangat } \\
\text { Tinggi }\end{array}$ \\
\hline & & $\begin{array}{l}\text { Fitur dalam aplikasi Mandiri Online sangat } \\
\text { membantu saya dalam bertransaksi }\end{array}$ & 441 & $\begin{array}{l}\text { Sangat } \\
\text { Tinggi }\end{array}$ \\
\hline 2 & Renaming & $\begin{array}{l}\text { saya menyukai nama brand aplikasi Mandiri } \\
\text { Online yang terbaru }\end{array}$ & 429 & $\begin{array}{l}\text { Sangat } \\
\text { Tinggi }\end{array}$ \\
\hline \multirow{2}{*}{3} & \multirow{2}{*}{ Redesign } & $\begin{array}{l}\text { saya mengetahui logo aplikasi Mandiri } \\
\text { Online melalui media iklan atau media sosial }\end{array}$ & 386 & Tinggi \\
\hline & & $\begin{array}{l}\text { saya mengetahui slogan aplikasi Mandiri } \\
\text { Online yang terbaru }\end{array}$ & 354 & Tinggi \\
\hline \multirow[t]{3}{*}{4} & Relaunch & $\begin{array}{l}\text { Saya mengetahui kapan aplikasi Mandiri } \\
\text { Online diluncurkan }\end{array}$ & 321 & Sedang \\
\hline & \multicolumn{2}{|l|}{ Total } & \multicolumn{2}{|l|}{2800} \\
\hline & \multicolumn{2}{|l|}{ Rata - Rata } & \multicolumn{2}{|l|}{$\begin{array}{l}400 \\
\text { (Tinggi) }\end{array}$} \\
\hline
\end{tabular}

Sumber : Hasil Pengolahan Data

Untuk variabel Rebranding mencapai skor 400, yang dapat dikategorikan tinggi, artinya Rebranding mandiri online di KCU Bandung Surapati sudah baik. Berikut resume tanggapan responden untuk variabel Brand Equity. 
Tabel 3. Resume Brand Equity

\begin{tabular}{|c|c|c|c|c|}
\hline No. & Indikator & Pernyataan & Skor & Kriteria \\
\hline 1 & $\begin{array}{l}\text { Kesadaran } \\
\text { Merek }\end{array}$ & $\begin{array}{l}\text { Saya mudah mengingat brand aplikasi Mandiri } \\
\text { Online di banding aplikasi lainnya yang sudah } \\
\text { saya pakai }\end{array}$ & 340 & Tinggi \\
\hline \multirow{2}{*}{2} & \multirow{2}{*}{$\begin{array}{l}\text { Asosiasi } \\
\text { Merek }\end{array}$} & $\begin{array}{l}\text { Aplikasi Mandiri Online aman di banding } \\
\text { aplikasi lainnya yang sudah saya pakai }\end{array}$ & 420 & Tinggi \\
\hline & & $\begin{array}{l}\text { Aplikasi Mandiri Online dapat di download } \\
\text { dengan gratis di App Store atau Play Store }\end{array}$ & 451 & $\begin{array}{l}\text { Sangat } \\
\text { Tinggi }\end{array}$ \\
\hline \multirow{2}{*}{3} & \multirow{2}{*}{$\begin{array}{l}\text { Persepsi } \\
\text { Kualitas }\end{array}$} & $\begin{array}{l}\text { Saya mendapatakan banyak fitur untuk transaksi } \\
\text { yang sebelumnya tidak saya ketahui }\end{array}$ & 431 & $\begin{array}{l}\text { Sangat } \\
\text { Tinggi }\end{array}$ \\
\hline & & $\begin{array}{l}\text { aplikasi Mandiri Online yang digunakan jarang } \\
\text { terjadi masalah atau error }\end{array}$ & 357 & Tinggi \\
\hline \multirow{4}{*}{4} & \multirow{2}{*}{$\begin{array}{l}\text { Loyalitas } \\
\text { Merek }\end{array}$} & $\begin{array}{l}\text { Saya menyukai brand aplikasi Mandiri Online } \\
\text { yang sekarang }\end{array}$ & 415 & Tinggi \\
\hline & & $\begin{array}{l}\text { saya akan sering menggunakan aplikasi Mandiri } \\
\text { Online untuk bertransaksi }\end{array}$ & 402 & Tinggi \\
\hline & \multicolumn{2}{|r|}{ e } & \multicolumn{2}{|l|}{2816} \\
\hline & \multicolumn{2}{|l|}{ Rata - rata } & \multicolumn{2}{|l|}{$\begin{array}{l}402,28 \\
\text { (Tinggi) }\end{array}$} \\
\hline
\end{tabular}

Sumber : Hasil Pengolahan Data

Untuk variabel Brand Equity mencapai skor 402,28, yang dapat dikategorikan tinggi, artinya Brand Equity mandiri online di Bank Mandiri KCU Bandung Surapati sudah baik namun Brand Equity tersebut masih perlu ditingkatkan hingga mencapai maksimal.

\subsection{Korelasi Antar Variabel}

Tabel 4. Koefisien Korelasi

\begin{tabular}{|l|l|ll|l|}
\hline \multicolumn{2}{|l|}{} & \multicolumn{2}{|l|}{ Rebranding } & \multicolumn{2}{l|}{ Brand Equity } \\
\hline Rebranding & Pearson Correlation & 1 & $0,433 \quad 0,000$ \\
\hline Brand Equity & Pearson Correlation & $0,433 \quad 0,000$ & 1 \\
\hline
\end{tabular}

Sumber : Hasil Pengolahan Data

Berdasarkan hasil perhitungan pada tabel 4 tersebut diatas, dapat disimpulkan bahwa besarnya koefisien korelasi Rebranding dan Brand Equity adalah 0,433 yang berarti keduanya memiliki hubungan yang positif dan nilai signifikansi yang lebih kecil dari 0,05 yaitu sebesar 0,000 menunjukan bahwa hubungan keduanya adalah signifikan. 


\section{PENGUJIAN HIPOTESIS}

Pada pengujian hipotesis ini, yang dilakukan adalah uji t. Dengan hipotesis statistik yang diajukan adalah sebagai berikut :

$\mathrm{H}_{0}: \mathrm{b}_{1}=0, \quad$ Rebranding memiliki pengaruh tidak signifikan terhadap Brand Equity.

$\mathrm{H}_{1}: \mathrm{b}_{1}>0, \quad$ Rebranding memiliki pengaruh positif signifikan terhadap Brand Equity.

Tabel 5. Uji t

\begin{tabular}{|c|c|c|c|c|c|c|}
\hline \multirow{2}{*}{\multicolumn{2}{|c|}{ Model }} & \multicolumn{2}{|c|}{$\begin{array}{l}\text { Unstandardized } \\
\text { Coefficients }\end{array}$} & \multirow{2}{*}{$\begin{array}{l}\text { Standardized } \\
\text { Coefficients } \\
\text { Beta } \\
\end{array}$} & \multirow{3}{*}{$\begin{array}{l}\mathrm{T} \\
7,520 \\
\end{array}$} & \multirow{3}{*}{$\begin{array}{l}\text { Sig. } \\
, 000\end{array}$} \\
\hline & & \multirow{2}{*}{$\begin{array}{l}\mathrm{B} \\
2,550 \\
\end{array}$} & \multirow{2}{*}{$\begin{array}{l}\text { Std. Error } \\
, 339 \\
\end{array}$} & & & \\
\hline 1 & (Constant) & & & & & \\
\hline & $\begin{array}{l}\text { Rebrandin } \\
\mathrm{g}\end{array}$ & ,400 & ,084 & ,433 & 4,753 & ,000 \\
\hline
\end{tabular}

Sumber : Hasil Pengolahan Data

Berdasarkan hasil perhitungan pada tabel diatas diperoleh nilai signifikansi untuk variabel Rebranding sebesar 0,400. Karena tingkat signifikansi tersebut lebih kecil dari kriteria yang digunakan $(0.000<0,05)$, maka Rebranding memiliki pengaruh signifikan terhadap Brand Equity, serta hipotesis dapat dikonfirmasikan.

Tabel 6. Koefisien Determinasi

\begin{tabular}{|l|l|l|}
\hline Model & R & R Square \\
\hline 1 &, $433^{\mathrm{a}}$ &, 187 \\
\hline
\end{tabular}

Sumber : Hasil Pengolahan Data

Hasil analisis koefisien determinasi $\left(\mathrm{R}^{2}\right)$ menunjukkan bahwa persentase sumbangan pengaruh Rebranding terhadap Brand Equity adalah sebesar 18,7\%. Adapun sisanya sebesar $81,3 \%$ dijelaskan oleh variabel lain yang tidak diteliti dalam penelitian ini.

\section{DISKUSI DAN KETERBATASAN}

Berdasarkan hasil penelitian, Rebranding berpengaruh positif signifikan terhadap Brand Equity. Semakin diterapkan dengan baik Rebranding Mandiri Online pada Bank Mandiri KCU Bandung Surapati maka semakin tinggi Brand Equity. Penelitian ini 
mendukung penelitian yang dilakukan oleh Febriansyah (2013) dan Mariastuti (2015) dan tidak sejalan dengan penelitian Roslina (2013). Namun, koefisien regresi yang dihasilkan masih sangat kurang, yaitu hanya sebesar $18,7 \%$ dan sisanya sebesar $81,3 \%$ dari variabel lain yang tidak diteliti pada penelitian ini.

Sehingga implikasi praktis yang dapat diambil dari hasil penelitian ini adalah jika Bank Mandiri KCU Bandung Surapati ingin meningkatkan Brand Equity Mandiri Online, maka harus meningkatkan penerapan Rebranding. Terutama pada indikatorindikator yang dianggap masih kurang, seperti mengetahui peluncuran aplikasi mandiri online. Dengan cara memberikan pemberitahuan yang lebih detail dan juga lebih luas lagi agar para nasabah dapat mengetahui mengenai launching mandiri online.

Pada penelitian ini juga terdapat beberapa keterbatasan, diantaranya adalah kemungkinan adanya bias dari jawaban kuesioner, karena walaupun sudah dilakukan validasi, jawaban responden belum tentu mencerminkan keadaan sebenarnya, serta jumlah responden yang terbatas yaitu hanya 100, sehingga hasil penelitian tidak dapat digeneralisir pada ruang lingkup yang lebih luas seperti seluruh nasabah Bank Mandiri.

\section{DAFTAR PUSTAKA}

Amstrong, Gary, and Kotler, Philip. 2008. Marketing an Introduction $6^{\text {th }}$ Edition. Pearson Education Internasional, Prentice Hall, New Jersey.

Arikunto, S. 2002. Prosedur Penelitian, Suatu Pendekatan Praktek. Jakarta : Rineka Cipta.

Kotler, P.dan Amstrong, G. 2008. Prinsip-Prinsip Pemasaran. Penerbit Erlangga. Jakarta.

Lovelock, C. and L. Wright. 2002. Principles of Service Marketing and Management, $2^{\text {nd }}$ edition, Upper Saddle River; Pearson Education, Inc.

Lupiyoadi, Rambat, 2001, Manajemen Pemasaran Jasa Edisi Pertama, Salemba Empat, Jakarta.

Sugiyono, 2013. Metode Penelitian Kuantitatif Kualitatif dan R\&D. Penerbit Alfabeta Bandung.

Tjiptono, F. 2009. Service Marketing: Esensi \& Aplikasi. Penerbit Marknesis. Yogyakarta.

Umar, Husein. 2003. Studi Kelayakan Dalam Bidang Jasa, Cetakan Pertama. Jakarta. Gramedia. 